\title{
Fraud Detection Gap between Auditor and Fraud Detection Models: Evidence from Gulf Cooperation Council
}

\author{
Tahani Ali Hakami, Mohd Mohid Rahmat, Mohd Hasimi Yaacob \& Norman Mohd Saleh
}

\section{ABSTRACT}

This study investigates an auditor's fraud detection gap (FDG) in Gulf Cooperation Council (GCC) companies by comparing the result of the fraud detection models (namely the Beneish M-score, Dechow F-score, and Altman Z-score) with an actual of audit opinion given by the auditors. Prior scholars documented that financial models are accurate and important measurements in fraud detection. However, the majority of fraud cases in the region are revealed accidentally which indicates the unclear role of the internal and external auditor. The data consists of 365 companies operated in the GCC for the period from 2015 to 2017 with a total of 1,095 observations. The study found that the success rate of detecting financial statement frauds for Dechow F model is much higher than Beneish M or Altman Z models. The result also indicated that the highest FDG-score results were obtained by the Dechow F model. However, the Beneish M model can detect financial statements' fraud better for companies associated to local audit firms as compared to international audit firms. Additionally, Big 4 audit firms are associated with a lower FDG in Beneish M model but increase FDG in Altman $Z$ model. Hence, the study supported the inclusion of statistical models, to a certain extent, as an alternative or supplementary method that assisted in making better decision-making for companies within the Gulf States. The regulators, policy maker, and practitioners, mainly the audit firms must concern that the ability to detect financial statement's fraud can be enhanced by utilizing the appropriate fraud detection model.

Keywords: fraud detection gap; Beneish M-score; Dechow F-score; Altman Z-score; audit opinion.

\section{INTRODUCTION}

Financial statement frauds and other forms of fraud are a serious threat to all companies. The Association of Certified Fraud Examiners (ACFE) produced a report in 2016 that showed that the Middle East, including all the six Gulf Cooperation Council (GCC) countries has the lowest cases of fraud for only $3.7 \%$ of the total cases. However, the frauds are reported in the region involved the highest median loss globally from the fraud of $\$ 275,000$ per case compared to the global median loss of $\$ 150,000$ per case (ACFE 2016). This circumstance indicated that the GCC region has lower cases or frequencies of financial statement fraud, however, the magnitude or value of losses resulted from the incidences of financial statements fraud is huge.

According to PricewaterhouseCoopers's report, 2016 on economic crimes in the Middle East, the number of companies that reported frauds in the region stands at $26 \%$. The main concern of this study is about $17 \%$ of the fraud cases in the region that are accidentally revealed with whistle blower hotlines. The global average for frauds unearthed by accident in which not detected by the internal or external auditors is $11 \%$ (PwC 2016). In many occasions, fraud has been reported to have taken place even in organizations that have internal auditors, as well as audited by the external auditor. Additionally, since another report by PwC (2016) indicate the number of an undetected fraud case by auditors there is a view that the number of financial statement frauds committed in the GCC region could be significantly higher than the cases reported by the ACFE
(Kroll 2017). These circumstances raise critical question regarding to the ability of the auditor to detect any material misstatements or frauds in the financial statement.

In addition, prior studies documented that financial statement fraud detection models such as Beneish M score, Dechow F score and Altman Z-score are highly accurate and important measurement in fraud detection (Omar et al. 2014; Hung et al. 2017; MacCarthy 2017). Are the auditors aware and do they apply these fraud detection models to assess the fraud risk when they do the planning and performing part of the audit work? Otherwise, why did the auditors not give their opinion consistent with the models? While there is no evidence to indicate that auditor applying the fraud detection models in auditing fraud, this study raises concern over the fraud detection gap (FDG) between the auditor and the fraud detection models. Thus, this study investigates the FDG by using three renowned fraud detection models, i.e., Beneish M score, Dechow F score and Altman Z-score with the actual fraud reported by the auditor in his or her audit opinion in financial statements of Gulf Cooperation Council (GCC) companies. This study also aims to determine which the fraud detection models has the highest FDG score with the minimum FDG. Additionally, this study is expanded by investigating the association between the FDG and audit quality which is differentiated via international versus local or Big 4 versus non-Big 4 auditors.

FDG refers to the difference between the results of the fraud detection models and auditor's opinion reported in 
the client firm's financial reports. Financial fraud detection tools have been brought to scenic in order to address the fraud problem and to provide reliable solutions to business (Albashrawi 2016). The auditor's report is a report which contains the auditor's opinion about the reliability and fairness of the financial statements (Habib \& Muhammadi 2018). Aligned with the International Standard on Auditing (ISA) 240, auditors are responsible to detect any misstatements resulting from fraudulent activity, error and/ or non-compliance in the financial statement by performing the audit work. While detecting fraud is difficult as the fraudster may cover up the fraud with complete documentations, external auditors may rely on fraud detection models ${ }^{1}$ in order to help in identifying cases that require further investigation (Mangala \& Kumari 2017; Chan \& Vasarhelyi 2018). Evidently, there has been very limited research aimed at identifying the fraud detection models to the real external auditors' opinion especially in GCC region.

GCC consists of the six Arab monarch states among Bahrain, Kuwait, Oman, Qatar, Saudia Arabia and the United Arab Emirates in the Persian Gulf (Ramady 2012). The GCC firms are chosen because the region has the highest potential for unreported fraud as $17 \%$ of the region's fraud incidences are accidentally discovered (not by the internal or external auditors) (PwC 2016). The high rate of accidental fraud discoveries in the GCC because of the failure of companies in the region to undertake a fraud risk assessment, accounting irregularities and ineffective external audits (PwC 2016; Bahraw et al. 2016; Baatwah 2016). Companies face challenges of detecting and averting any form of fraud. Furthermore, as current or old techniques of fraud detection is detected, fraudsters develop new ways to create fraud which ultimately made the issue cyclic.

This study examined 365 of the listed companies in GCC region from 2015 to 2017 with a total of 1,095 firmyear observations. The study found that the success rate of detecting financial statement frauds for Dechow F model is much higher than Beneish M or Altman Z models. Gap analysis based on the FDG between the auditors' opinion and each of the three models indicated that FDG exists. The positive FDG means the auditor reports fraud but model(s) do not detect it. Similarly, the negative FDG means that the model indicates a fraud, but the auditor detects none. The result also indicated that generally, the highest FDG-score results are obtained by the Dechow F Score model than the Beneish $\mathrm{M}$ and the Altman $\mathrm{Z}$ models. Whereas, results showed that the Beneish M model can better detect fraud financial statements for companies with with local audit firms than international audit firms.

This paper significantly explores a new perspective, known as FDG. It concerns with FDG as the construct for observing the difference between the results of the prediction and actual audit opinion given by the auditors. It will also help to express the hidden aspect of fraud that auditors already are unable to detect it. This study also contributed to the literature by comparing the power between the three fraud models: Beneish M score, Dechow
F score and Altman Z-score in the detection fraud in GCC's firms since there was no prior study done in this region about it is assumed that a new strategy emerges, there are beneficiary and adopters. Therefore, this study hopes that it will contribute to both the practical and regulatory subject matters.

Section 2 describes the literature review and section 3 explains the research design, sample selection process and variable measurements. Section 4 ends with the results and conclusion.

\section{LiTERATURE REVIEW}

FRAUD AND FINANCIAL STATEMENT FRAUD IN GCC

Financial statement reports the fiscal position as well as the financial and economic activities of a firm or entity (Ittelson 2009; Wells 2017). The information is presented in a structured form that refers to jurisdictional accounting standards such as Generally Accepted Accounting Principles (GAAP) and International Financial Reporting Standards (IFRS) in order to maintain equivalence across financial statements. The primary objective of the financial statements is to provide users with information on the financial position of a firm in order to facilitate the appropriate allocation of resources (Hussey 2010).

Fraud can be classified into three categories: asset misappropriation, corruption, and fraudulent financial statements (ACFE 2007). Asset misappropriation is the first category of fraud. In essence, asset misappropriation entails misuse of an organization's resources. Generally, it involves employees or senior executives inflating an expense report, or inflating bills incurred. It also involves actual theft of cash meant for an organization's functions. It is the most common type of fraud (ACFE 2014). It touches almost all corporate organizations. Corruption is the second category of occupation fraud. Usually, corruption entails misuse of influence power for either direct or indirect gain. Corruption is not just limited to business organizations but is also rampant in the public sector. The third category for fraud is financial statement fraud. Previous studies observed that this type of fraud considers a serious concern for both investors and stakeholders (Hajek \& Henriques 2017). Ordinarily, this type of fraud entails manipulation of financial statements with an intention to create financial opportunities for company and the perpetrator (Gao \& Brink 2017).

Financial statement fraud is defined as an intentional act of manipulating financial statement through omissions or misstatements to create a false sense of a company's financial health by material misstatements in finance (Pietro 2018). It may also involve real transaction that indirectly affects the financial statement (Jian \& Wong 2010; Rahmat et al. 2018). The aim of such fraud is to mislead the users by either portraying superior performance to attract investors or by obscuring performance to limit tax liability (Kwok 2017). According to Zack (2012), 
financial statement fraud comprises of two broad categories, namely; timing manipulation and falsification of entries. Timing manipulation involves the inappropriate recognition of transactions through premature revenue recognition and/or postponement of expenses. Falsification of entries involves the recording of incorrect information through fictitious revenues, manipulation of asset valuations, manipulation of liabilities and expenses as well as falsified disclosures (Zack 2012). As the whole world faces these categories of fraud, it will be interesting to have a closer look as the Middle East and North Africa region especially GCC countries and it has relationship to FDG. The term occupational fraud and abuse is used to refer to fraud (ACFE). It defines as the use of a person's occupation to enrich oneself by deliberately misusing or misapplying companies' resources or assets. The term covers the fraud done by employees, managers, executives, or owners of the companies that is the victim of the fraud (ACFE 2016).

\section{ROLE OF AUDITORS IN FRAUD DETECTION AND FRAUD DETECTION MODELS}

Auditor's responsibility to detect fraud in financial statement is stated under ISA 240 Frauds. Basically, the auditor is not and cannot be held responsible for the prevention of fraud as the fact that an annual audit is carried out may act as a deterrent. In planning the audit, the auditor should assess the risk that fraud and error may cause the financial statements to contain material misstatements. Based on the risk assessment, the auditor should plan good audit procedures to ensure that they detect the whole misstatements arising from fraud or error on the financial statements. Furthermore, auditors are required to communicate to the management in writing whenever they suspect fraud has occurred and are also legally obliged to communicate to a supervisory body whenever material fraud is detected (Krambia-Kapardis 2010). An external audit could now be actively pursued and passively depending on the company's circumstances. Therefore, this can serve as one of the major importance of good audit characteristic in detecting fraud. In the important role and responsibilities of auditors, good auditor characteristics are essential in detecting fraud. However, the auditor's failure to reveal many recent of accounting scandals, particularly involving large companies around the globe to increase awareness about the auditor's competency in detecting the financial fraud.

The increasing economic burden and financial losses due to financial fraud have underscored the significance of equipping accounting professionals with effective fraud detection tools and techniques. The financial statement frequency of fraud cases relative to occupational fraud cases increased from $7.6 \%$ in 2012 to $9.6 \%$ (ACFE 2016). The rising number of financial statement fraud case globally indicated that auditing work could be insufficient in detecting fraud, and with time, amalgamation and sophistication of fraud schemes, fraud detection has increasingly become a complex endeavour (Ravisankar et al. 2011; Paik et al. 2018). Chan and Vasarhelyi (2018), studied that, conventional auditing methods may be ineffective in detecting financial statement fraud due to a lack of knowledge and experience accounting fraud among auditors. The infrequent nature of fraudulent manipulation also makes it difficult for external auditors to detect falsified accounting information, especially when perpetrated by senior management (Fanning \& Cogger 1998). Therefore, continuous auditing with fraud detection tools to augment the efficiency of the audit process are recommended for timely fraud detection. Thus, audit quality and auditor experience with a client including fraud detection tools are some of the factors to enhance fraud detection (Stephens 2011).

Fraud detection models are among the tools and procedures that control, automate and screen to detect accounting fraud under the specialized forensic accounting field (Silverstone \& Sheetz 2004). Thus, external auditors may also rely on the fraud detection models in order to identify cases that require further investigation. To fulfil the requirements of better audit quality, it is crucial for the auditors to verify the accuracy of financial statements to reveal any manipulation by adopting various tools and fraud detection models, which can assist them in detecting fraud. Evidently, there is no research conducted to identify the fraud detection models to the real external auditors' work and if the auditors really used models to detect fraud.

Fraud detection does not occur as frauds are hidden from the eyes of the auditors. It could be the smart manipulation that not easily detected by the old or normal technics used. This is evident from the many fraud cases happening within the many organizations. However, various models have been developed by the experts with the aim of helping the auditors do the analysis of the financial statements and assessment of any probability that fraud has occurred or likely to occur. Thus, these tools are sophisticated and consist of the financial ratios making them most suitable to carry out fraud detection (Aghghaleh et al. 2016). These models have been developed by the research in accounting to detect fraud, bankruptcy, earning management and manipulation. Among the highly regarded models are Dechow F-score, Beneish M-score and Altman $\mathrm{Z}$-score models. Although the Altman $\mathrm{Z}$ model is primarily used to predict company's bankruptcy, its use as an essential part of each audit while complementing other models such as Beneish M-Model is recommended because of the association between bankruptcy and financial fraud (MacCarthy 2017). The identified models are the most known for best utilization of the financial ratios thus found suitable for usage by most of the auditors. Prior studies have thrown their support to the use of financial ratios in forecasting business failure, detection of fraud and evaluation of performance (Al Ghamdi 2012). Further expansion of the ability to use of ratios in the models has boasted by classifying the types of financial ratios used for each model. 


\section{BENEISH M-SCORE MODEL}

The Beneish M-score model is a mathematical model that utilizes financial ratios based on financial statement data in order to determine the likelihood of a firm to manipulate its reported earnings. The model relies on eight financial ratios to compute the Beneish M-score, which is used to determine the probability of financial manipulation (Beneish 1999). Consequently, the model is a probability reliant model implying that it cannot accurately detect financial manipulation but rather highlights the probability of the occurrence of financial manipulation. The model weights each of the ratios with a predetermined coefficient to identify firms with high incentives to manipulate their reported earnings (Beneish 1999).

The Beneish M-score model has been extensively used to empirically investigate the propensity for financial statement manipulation across firms and jurisdictions. For instance, Omar et al. (2014) utilized the model to examine the financial statements of the Malaysian firm, Megan Media Holdings Berhad (MMHB), for the period between 2005 and 2007. The findings indicated that the firm had the Beneish M-score of 0.863 which is significantly higher than the -2.22 thus, gave an indication of MMHB that it had manipulated its earnings (Omar et al. 2014). Repousis (2016) also applies the Beneish M-score model to examine the financial statements of 25,468 firms in Greece for the 2011 and 2012 financial periods. Earning management in the study is expressed as the results of eight variables of Beneish M-score. The results reveal that $33 \%$ of the sampled firms have an M-score than is greater than -2.2. In addition, the findings highlight significant positive relationship between earning management and all eight Beneish M-score model variables, with Days' Sales in Receivables Index (DSRI) having the highest coefficient of determination of $95.92 \%$ (Repousis 2016). The results therefore signalled financial statements manipulation within the identified firms with premature revenue recognition occurring in most of the cases.

\section{ALTMAN Z-SCORE}

The Altman Z-score is a statistical measure of the probability of a firm going bankrupt within two years. The Z-score is based on information obtained from the financial statements of a firm, with the formula accounting for the liquidity profitability, solvency, share market value and asset turnover of the firm. Generally, firms that have a $\mathrm{Z}$-score higher than 3.0 are considered safe from bankruptcy while firms with a Z-score below 1.8 are considered to have a higher insolvency risk (Aris et al. 2015). According to Altman (2000), the initial model was developed to analyse publicly traded manufacturing firms with an asset base equal to or exceeding of $\$ 1$ million, but, with the emergence of public service-based firms and growth of the private entities, the model has since been modified to examine those firms. Mahama (2015) applied the Z-score to Enron's unaudited financial statements for the period between 1996 and 2001. The findings revealed that the company has already signalled financial distress in 1997 due to a Z-score of 1.611.

In addition, Mahama (2015) utilized the Beneish M-score model to examine Enron's financial statements and the results showed that the company began manipulating its financial statements in 1998. Consequently, Mahama (2015) hypothesized that the manipulation of Enron's financial statements in 1998 occurred in an effort to conceal the financial distress detected by the Z-score in 1997. These findings are consistent with the findings of Ofori (2016) as well as MacCarthy (2017) who utilized the M-score and Z-core to examine Enron's financial statements for the period between 1996 and 2001.

\section{DECHOW F-SCORE}

The F-score developed by Dechow, Ge, Larson and Sloan (2011), is a probability-oriented metric that is used to determine the likelihood of a firm having misstatements in its financial statements. Considering that most material misstatements are predicated on fraud, the F-Score is regarded as a tool for detecting fraudulent financial reporting. Dechow et al. (2011) developed three models that relied on financial statement data, non-financial variables and market data. However, their first model only required inputs obtained from financial statements to compute the F-score. The model relied on 7 key variables, namely: RSST accruals which measures discretional accruals, change in receivables, change in inventory, percentage of soft assets, change in cash sales, change in return on assets, and actual issuance (Dechow et al. 2011, p.60). The normal F Score is 1 while a score higher than 1 indicated that there is a statistically higher probability that the financial statements of a firm contain misstatements. Conversely, an F-score of less than 1 indicated that there is relatively low risk of financial misstatements.

Hung et al. (2017) used the F-score model by Dechow et al. (2011), to investigate the probability of fraudulent financial reporting in the financial statements of firms listed on the Ho Chi Minh Stock Exchange in Vietnam. They also re-examined the relationship between all the F-score components (RSST accrual (Rsstacc), change in receivables (Chrec), change in inventory (Chinv), soft assets (Softassets), change in cash sales (Chcs), change in ROA (Chroa), actual issuance of stock (Issue), return on assets (ROA), the size of enterprises by revenue (Size) and financial leverage (LV)) and the likelihood of fraud. The findings of their studies revealed that Rsstacc, Chrec and Soft Assets are positively and significantly associated with the likelihood of fraud. The likelihood of fraud is calculated according to the F-score model, which the fraud risk exists when the F-score value is more than 1 , and the risk is considered high and very high when the F-score value is more than 1.85 and 2.45 respectively. The model utilized by Hung et al. (2017) was also shown to have a fraud predictive capacity of approximately 78\%. Aghghaleh et al. (2016) empirically investigated the fraud detection and predictive capabilities 
of the Beneish M-score and the Dechow F-core based on the financial ratios of listed companies in Malaysia from 2001 to 2014. Based on the financial ratios used from both the Beneish M-score model and Dechow F-score model, the results showed that both models have high efficiency in detecting fraudulent financial reporting, with the Beneish model having an average accuracy of $73.17 \%$ while the Dechow model has an accuracy of $76.22 \%$ (Aghghaleh et al. 2016). In addition, the results further indicated that the Dechow F-score has a relatively higher performance than the Beneish M-score in predicting fraud due to the model's higher sensitivity of 73.17 compared to the $69.51 \%$ sensitivity rate of the Beneish M Score (Aghghaleh et al. 2016). The Dechow F-score also has a lower type II error compared to the Beneish M-score implying that the Dechow F-score is more effective in detecting and predicting fraudulent financial reporting among listed firms in Malaysia (Aghghaleh et al. 2016).

This can be justifying by relying on the models supposed to be auditors' indicator of fraud detection. Unfortunately, auditors' opinion was not consistent with the models, will lead to uncertainty and create fraud detection gaps. The proposed models employed in this study are the Beneish M-score, Altman Z-Score, and Dechow F-score.

\section{AUDITORS' FRAUD DETECTION GAPS AND AUDIT QUALITY}

Consistent with the agency theory, the high audit service providers have a capability in detecting fraud. Thus, we predict the Big 4 auditors or international accounting firms that can detect fraud more accurately than non-Big 4 or local auditors because they have sufficient fund and resources to do so, an in addition, they deserve to protect their reputation (Che et al .2018). Many prior studies have proven that high quality audit, particularly provided by the Big 4, recommends positive impacts, for example reduce earnings management, enhance earnings quality, reduces wealth expropriation activities and many others. However, we find limited evidence to show that high audit quality is related to high probability to detect frauds, particularly in the context of FDGs. Therefore, we aligned with the theory perspective to develop the hypotheses that (1) there is a significant difference in FDG between international and local audit firm, and (2) there is a significant difference in FDG between Big 4 and non-Big
4 auditors, which the high audit quality (international/Big 4 auditors) is related to less FDG.

\section{Research Methodology}

The initial sample of non-financial companies comprises of 451 with total observation of 1,353 from Saudi Arabia, Bahrain, Kuwait, Oman and the United Arab Emirates of the GCC region from 2015 to 2017 . This period was selected for the availability of the data. The data were collected from DataStream by Thomson Reuters, and annual reports from company's website to obtain the auditor's opinion. However, the final sample used in this study consisted of 365 samples of non - financial firms with total observations of 1,095 after eliminating 86 companies with missing data.

Table 1 showed the sample distribution by countries and auditors. Most of the companies in the sample are in Saudi Arabia (34.8\%) followed by Kuwait (28.8\%). About $61 \%$ of the companies are audited by Big 4 . Generally, a higher percentage of the companies in Bahrain, Kuwait, Oman and UAE are audited by Big 4 except Saudi Arabia.

\section{OPERATIONALIZATION OF VARIABLES}

The dependent variable, FDG is measured by obtaining the difference between the actual fraud detected by the auditor as reported in his or her audit opinion and the prediction of fraud identified based on fraud detection models, including F-score model by Dechow, Beneish M-score model and Altman Z-score. In details, the FDG will be measured through the following steps:

1. Potential of fraud is determined by using the three fraud detection models. We calculate the fraud detection score derived by the result of the three models. If the score fulfils the criteria of fraud companies, the firm is coded as 1 , and otherwise 0 .

2. Determine the type of audit opinion issued by the auditors. If the auditor gives a clean audit report, the firm is scaled as 0 , and if the audit opinion is qualified due to any material misstatement (fraud, error or non-compliance) is coded as 1 .

3. Determine FDG by comparing the two determined scores. If the result is similar, means no gap, the observation is coded as 1 , and otherwise a gap (the results are not similar) is coded as 0 . In details, if the

TABLE 1. Sample Distribution by Countries and Auditors

\begin{tabular}{lccc}
\hline Country & Number of company-year observations (\%) & Audited by Big 4 (\%) & Audited by non-Big 4 (\%) \\
\hline Saudi Arabia & $381(34.8 \%)$ & $181(16.5 \%)$ & $200(18.3 \%)$ \\
Bahrain & $51(4.7 \%)$ & $36(3.3 \%)$ & $15(1.4 \%)$ \\
Kuwait & $315(28.8 \%)$ & $197(18.0 \%)$ & $118(10.8 \%)$ \\
Oman & $198(18.1 \%)$ & $127(11.6 \%)$ & $71(6.5 \%)$ \\
UAE & $150(13.7 \%)$ & $126(11.5 \%)$ & $24(2.2 \%)$ \\
Total & $1,095(100 \%)$ & $667(60.95 \%)$ & $428(39.1 \%)$ \\
\hline
\end{tabular}


FDG has a positive sign mean auditor detect fraud but the model detects no fraud, and the negative sign means the model detects fraud but the auditor does not detect it. However, this study only analyses the FDG without considering the direction of the FDG.

We summarize the determination of these three fraud detection models' scores and they are illustrated below:

The first model, Dechow F-Score model is computed by using the following formula:

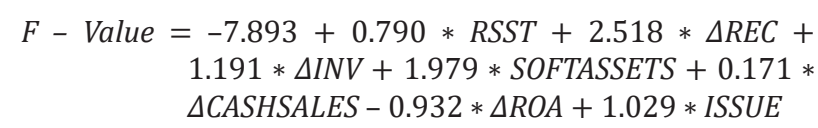

Where, RSST is RSST Accruals, which refers to a variable used for measuring changes in current assets without including cash, used to subtract the changes in current liabilities and depreciation without including shortterm debt. $\triangle \mathrm{REC}$ is change in receivables, which refers to changes in receivables calculated from previous year to current year as scaled by averages of total assets. $\triangle \mathrm{INV}$ is change in inventory, which refers to changes in inventories from previous year to current year as scaled by averages of total assets. SOFTASSETS is soft assets that refer to the measure that is defined by total assets minus the sum of PPE as well as cash with cash equivalents as scaled by averages of total assets. $\triangle$ CASHSALES is change in cash sales that refers to a measure that is expressed as percentage change of cash sales from previous year to current year. $\triangle \mathrm{ROA}$ is change in ROA that refers to a measure that is expressed as percentage of total earnings in terms of division of total assets in previous year which is less than the same measure in current year. ISSUE is actual issuance of stock that is measured by a dummy variable. By default, it is always 1 , in case additional securities are added within the manipulation year. However, the value is 0 , when no security is added.

Then, the fraudulent or non-fraudulent is determined by the product of (VALUE)/(1+ VALUE), which is then divided by a standard value of $(=0.0037)$ known as unconditional probability of misstatement. A score that is less than 1 indicates a company does not manipulate its financial statements. However, a score greater than 1.0 indicates an above-normal risk (that is, about 73 percent probability that the company manipulates its statements), a score greater than 1.85 indicates a high risk (that is, about 86 percent probability that the company manipulates its statements), and a score greater than 2.45 indicates a very high risk of accounting manipulation (that is more than 90 percent probability that the company manipulates its statements) (Kozlov et al. 2018).

Additionally, eight financial ratios used in computing the model Beneish M-score are: Days' Sales in Receivables Index (DSRI), Gross Margin Index (GMI), Asset Quality Index $(A Q I)$, Sales Growth Index $(S G I)$, Depreciation $(D E P I)$, Sales General arid Administrative Expenses(SGAI),
Total Accruals to Total Assets (TATA), and Leverage Index $(L V G)$ (Beneish 1999).

Specifically, the M- Beneish M-score model is calculated by using the following formula:

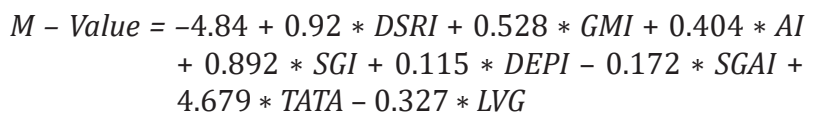

Where, DSRI $=\left(\right.$ Net Receivables ${ }_{\mathrm{t}} /$ Sales $\left._{\mathrm{t}}\right) /(\mathrm{Net}$ Receivables $_{\mathrm{t}-1} /$ Sales $\left._{\mathrm{t}-1}\right) ; G M I=\left[\left(\right.\right.$ Sales $_{\mathrm{t}-1}-$ Cost of Goods Sold $\left._{\mathrm{t}-1}\right) /$ Sales $\left._{\mathrm{t}-1}\right] /\left[\left(\right.\right.$ Sales $_{\mathrm{t}}-$ Cost of Goods Sold $) /$ Sales $\left._{\mathrm{t}}\right]$; $A Q I=\left[1-\left(\right.\right.$ Current Assets $_{\mathrm{t}}+\mathrm{PPE}_{\mathrm{t}} /$ Total Asset $\left.\left._{\mathrm{t}}\right)\right] /[1-$ (Current Assets $_{\mathrm{t}-1}+\mathrm{PPE}_{\mathrm{t}-1} /$ Total Asset $_{\mathrm{t}-1)}$ ]; $S G I=$ Sales $_{\mathrm{t}} /$ Sales $_{\mathrm{t}-1} ; D E P I=\left[\right.$ Depreciation $_{\mathrm{t}-1} /$ Depreciation $\left._{\mathrm{t}-1}+\mathrm{PPE}_{\mathrm{t}-1}\right]$ $/\left[\right.$ Depreciationt / Depreciationt $\left.+\mathrm{PPE}_{\mathrm{t}}\right] ; S G A I=[$ sales, general and administrative expenses / Sales $_{t}$ / [sales, general and administrative expenses $\left.{ }_{\mathrm{t}-1} / \mathrm{Sales}_{\mathrm{t}-1}\right]$; TATA $=$ Total Accruals ${ }_{t} /$ Total Assets $;$; LEVI $=\left[\operatorname{LTD}_{\mathrm{t}}+\right.$ Current Liabilities $_{t} /$ Total Assets $\left._{t}\right] /\left[\right.$ LTD $_{t-1}+$ Current Liabilities $_{t-1}$ / Total Assets t-1 $_{\text {] }}$ ]

Finally, the third model, the Altman Z-Score is calculated by using the following formula:

$$
\begin{aligned}
Z-\text { Value }= & 0.012 X 1+0.014 X 2+0.033 X 3+0.006 X 4 \\
& +0.999 X 5
\end{aligned}
$$

Where: $X 1=$ working capital/total assets; $X 2=$ retained earnings/total assets; $X 3=$ earnings before interest and taxes/total assets; $X 4$ = market value equity/book value of total liabilities; $X 5=$ sales/total assets.

In equations (2), (3), .. (6), X1, X2, .. X5 are the metrics that emerge from the accounting ratios (Mahama 2015). The metrics presented are a construct of the different forms of ratios such as business activity and profitability. The formula measures the liquid assets of the company against its size, the profitability and earning power of a company all while ensuring that operating earnings and market dimensions are regarded. Finally, it also assesses the total measure of asset turnover.

\section{RESULTS}

\section{DESCRIPTIVE ANALYSIS}

Three statistical models were adopted namely Dechow F-score, Beneish M-Score and Altman Z-Score to compare their ability with auditor's work to detect financial statement fraud. The finding indicated that both models and auditor's able to detect fraud but there is gap between them. This means that in some cases, the auditors cannot predict fraud while the models predict and vice versa is true. The success rate of the auditors, and the three statistical models in terms of detecting financial statement fraud suggested that, Dechow F-score model manage to detect $20.5 \%$ of the observations as fraud as compared to Beneish M-score model (12.4\%), Altman Z-score model $(11.0 \%)$ and the auditors $(10.9 \%)$. Further analysis using 
detection gap information suggested that, Dechow F-score model is able to detect fraud for $12.8 \%$ of the sample observations while Altman Z-score model is able to detect $10.2 \%$ and Beneish $\mathrm{M}$-score model is able to detect $9.5 \%$ of the total observations. Thus, the high percentage for Dechow F-score model showed some evidence that the model is able to detect fraud better than the other two models. Table 2A showed some statistics for the FDG between the auditor and each of the three models.

The table showed the FDG values for Dechow F-Score model, Beneish M-score model, and Altman Z-score model are $-0.10,-0.02$ and -0.03 , respectively. Dechow F-score model produces the largest gap value $(-0.10)$ which suggests that the higher auditor's FDG is driven from the Dechow F -score model. The gap is negative that indicating auditors do not find or report any misstatement but the Dechow F-score model predicted it. The FDGs related to Beneish model and Altman model are very close to zero implying that generally there is no difference between the evaluations of the auditors and the models. In all cases, the minimum and maximum values are -1 and +1 , respectively. It indicates that in certain circumstances, the auditors can detect fraud and vice versa. Inferential analysis further performed to support the research hypotheses. The breakdown of the sample as depicted in Table 2A also showed that 60.9\% (667 companies) are audited by Big 4 audit firms while $39.1 \%$ are audited by non-Big 4.

Table 2B showed statistics for the FDG between the auditor and each of the three models by Big 4 and non-Big 4 and by international and local, respectively. The mean values in Table 2B, Panel A showed that Dechow F-score model produced the largest gap value for both Big 4 and non-Big 4 companies. This suggested that the higher auditor's FDG which is driven from the Dechow F -score model. The negative gap value indicated that the auditors do not find or report any misstatement but the Dechow F-score model predicted it. Table 2B, Panel B showed a similar result was found for the international audit firms. However, for local audit firms, the Beneish M-score model seemed to perform better. This might be due to the imbalanced sample breakdown of $92 \%$ international and $8 \%$ local audit firms.

Additionally, Table 3 illustrated the results for FDGs analyses by comparing the three fraud detection models, Dechow F, Beneish M and Altman Z. The FDG score is calculated by the number of correct predictions made divided by the total of predictions made, and multiplied by 100 to turn it into a percentage. Higher FDG scores indicate lower fraud detection gap between auditors and the fraud detection model. The statistics showed that the capability of the auditors to give audit opinions is higher than the result calculated by the models. The FDG scores are $84.4 \%, 83.5 \%$ and $82.7 \%$ generated by the Dechow F, Beneish $\mathrm{M}$ and Altman Z models respectively. The Dechow F produced the lowest FDG with 171 cases, Beneish M with 181 cases, and the highest FDG is in the Altman $\mathrm{Z}$ model with 189 cases.

The results also showed that auditors $(81.9 \%)$ are more reliable in detecting fraud than the Dechow $\mathrm{F}$ model (18.1\%). However, the auditors (around 60\%) are slightly reliable in detecting fraud than the Beneish $\mathrm{M}(42.5 \%)$ and Altman Z models (40.7\%). As for Big 4 audit firms, the auditors are more reliable in detecting fraud as compared to Dechow F and Altman Z models. To be more specific, the auditors are $81.4 \%$ of the time more reliable than the Dechow F model whereas, they are $62.9 \%$ of the time more reliable than the Altman $\mathrm{Z}$ model. The auditors

TABLE 2A. Descriptive Analysis

\begin{tabular}{lccccc}
\hline Variable & Mean & Median & Minimum & Maximum & Std. Deviation \\
\hline FDG-Dechow F & -0.10 & 0.00 & -1 & 1 & 0.38 \\
FDG-Beneish M & -0.02 & 0.00 & -1 & 1 & 0.41 \\
FDG-Altman Z & -0.03 & 0.00 & -1 & 1 & 0.41 \\
Big 4 & \multicolumn{2}{c}{ Big $4(667,60.9 \%)$ Non Big $4(428,39.1 \%)$} & 0.54 \\
BInd & 0.55 & 0.44 & 0 & 7 & 0.29 \\
ACInd & 0.83 & 1.00 & 0 & 3 & 2.58 \\
FSize & 12.70 & 12.61 & 2.75 & 19.92 & 20.40 \\
FLev & 20.84 & 17.27 & 0 & 203.31 & 37.62 \\
ProfitM & 26.76 & 25.28 & -432.66 & 100.0 & 10.22 \\
ROA & 4.53 & 4.60 & -164.07 & 73.70 & \\
\hline
\end{tabular}

Note: FDG-Dechow F is FDG measured by the comparing between auditors' opinions and F-score, FDG-Beneish $M$ is FDG measured by the comparing between auditors' opinions and M-score, FDG-Altman $Z$ is FDG measured by the comparing between auditors' opinions and Z-score-Big4 represents quality of the audit services, measure as a dummy, equal to 1 if the companies appoint Big 4 auditor, and 0 otherwise; BInd is a board independence, measured by ratio of independent directors over total board members; $A C I n d$ is an audit committee independence, measured by ratio of independent directors over total audit committee members; FSize is a firm size, measured as a natural logarithm of the companies' total assets; FLev is a firm leverage, measured by scaling the companies' total debts over total assets; ProfitM is a gross profit margin, which measured by dividing gross profit to total sales; $R O A$ is return on assets, calculated by scaling the companies' net earnings to total assets; $\varepsilon$ is representing an error term. 
TABLE 2B. Descriptive Analysis for Audit Firm Size and Internationalization

\begin{tabular}{|c|c|c|c|c|c|c|}
\hline \multicolumn{7}{|c|}{ Panel A - Descriptive Analysis for Big 4 verse non-Big 4} \\
\hline \multirow[t]{2}{*}{ Variable } & \multicolumn{2}{|c|}{ Mean } & \multicolumn{2}{|c|}{ Median } & \multicolumn{2}{|c|}{ Std. Deviation } \\
\hline & Big 4 & non-big 4 & Big 4 & non-big 4 & Big 4 & non-big 4 \\
\hline FDG-Dechow F & -0.09 & -0.11 & 0.00 & 0.00 & 0.37 & 0.40 \\
\hline FDG-Beneish M & 0.00 & -0.06 & 0.00 & 0.00 & 0.39 & 0.43 \\
\hline FDG-Altman Z & -0.05 & 0.00 & 0.00 & 0.00 & 0.44 & 0.37 \\
\hline BInd & 0.58 & 0.48 & 0.44 & 0.43 & 0.66 & 0.24 \\
\hline ACInd & 0.82 & 0.83 & 1.00 & 1.00 & 0.28 & 0.31 \\
\hline FSize & 13.05 & 12.15 & 12.94 & 12.37 & 2.59 & 2.48 \\
\hline FLev & 21.47 & 19.86 & 18.59 & 14.80 & 19.14 & 22.21 \\
\hline ProfitM & 29.17 & 17.13 & 26.89 & 22.88 & 28.11 & 131.97 \\
\hline ROA & 5.44 & 3.10 & 5.17 & 3.32 & 8.31 & 12.52 \\
\hline \multicolumn{7}{|c|}{ Panel B - Descriptive Analysis for International verse Local } \\
\hline \multirow[t]{2}{*}{ Variable } & \multicolumn{2}{|c|}{ Mean } & \multicolumn{2}{|c|}{ Median } & \multicolumn{2}{|c|}{ Std. Deviation } \\
\hline & International & Local & International & Local & International & Local \\
\hline FDG-Dechow F & -0.10 & -0.06 & 0.00 & 0.00 & 0.38 & 0.37 \\
\hline FDG-Beneish M & -0.02 & -0.13 & 0.00 & 0.00 & 0.40 & 0.46 \\
\hline FDG-Altman Z & -0.04 & 0.01 & 0.00 & 0.00 & 0.42 & 0.30 \\
\hline BInd & 0.54 & 0.58 & 0.43 & 0.63 & 0.55 & 0.21 \\
\hline ACInd & 0.82 & 0.95 & 1.00 & 1.00 & 0.30 & 0.21 \\
\hline FSize & 12.63 & 13.60 & 12.48 & 13.50 & 2.62 & 1.85 \\
\hline FLev & 21.27 & 15.37 & 17.48 & 14.48 & 20.71 & 14.97 \\
\hline ProfitM & 24.74 & 20.98 & 25.27 & 25.81 & 87.56 & 52.83 \\
\hline ROA & 4.61 & 3.44 & 4.71 & 2.62 & 10.42 & 7.21 \\
\hline
\end{tabular}

Note: Please refer to Table 2A for definition and measurement of the variables.

TABLE 3. Analysis for FDGs for Models F, M and Z

\begin{tabular}{lccccccccc}
\hline & \multicolumn{3}{c}{ Model Dechow F } & \multicolumn{3}{c}{ Model Beneish M } & \multicolumn{3}{c}{ Model Altman Z } \\
\cline { 2 - 9 } & Big 4 & Others & Total & Big 4 & Others & Total & Big 4 & Others & Total \\
\hline \multirow{2}{*}{ Positive FDG } & 79 & 61 & 140 & 52 & 52 & 104 & 83 & 29 & 112 \\
& $(81.4 \%)$ & $(82.4 \%)$ & $(81.9 \%)$ & $(51.0 \%)$ & $(67.5 \%)$ & $(57.5 \%)$ & $(62.9 \%)$ & $(50.9 \%)$ & $(59.3 \%)$ \\
Negative FDG & 18 & 13 & 31 & 50 & 27 & 77 & 49 & 28 & 77 \\
& $(18.6 \%)$ & $(17.6 \%)$ & $(18.1 \%)$ & $(49.0 \%)$ & $(32.5 \%)$ & $(42.5 \%)$ & $(37.1 \%)$ & $(49.1 \%)$ & $(40.7 \%)$ \\
Total & 97 & 74 & 171 & 102 & 77 & 181 & 132 & 57 & 189 \\
Non-FDG & & & 924 & & & 914 & & & 906 \\
FDG Score & & & $84.4 \%$ & & & $83.5 \%$ & & & $82.7 \%$ \\
\hline
\end{tabular}

Notes: Negative FDG is the model detects fraud, but the auditor detect non-fraud; Positive FDG is the auditor detects fraud but the model detect non-fraud. If the result from the model is (0), and auditor's opinion is the same (0) or model is (1), and auditor's opinion is the same (1) both derive to become non-FDG.

and Beneish M model performance in detecting fraud are quite similar.

\section{UNIVARIATE ANALYSIS}

The distribution of the sample observations where $92.8 \%$ consists of companies associated with international audit firms while $7.2 \%$ is from local audit firms (not tabulated). International audit firms refer to global audit firms while local audit firm only the national firms. As can be seen the distribution of the observations is very unbalanced. The presence of this large disparity of observations between the two types of company may have an impact on the results of hypothesis testing hence leading to inconclusive findings. Hence, fair comparisons between international and local companies is highly not recommended. Thus, we run a nonparametric test known as the Wilcoxon test to examine whether there is a significant difference in FDG 
between the used three models i.e., the Dechow F-Score model, the Beneish M-Score model and the Altman Z-Score model, respectively.

The results of the differences for each pair is as shown in Table 4, Panel A. The statistics supported the fact that the FDG is statistically significant only between auditors and the Dechow F-score model $(\mathrm{Z}$-value $=-8.130$, $\mathrm{p}$ - value $<0.01)$. Then, we run additional analysis to determine whether the FDG scores among the three models differ significantly. The Friedman test is used to compare the gaps across the board for the three models, and the results of the test are presented in Table 4, Panel B. The large Chi-square value of 38.087 and the $p$-value $<0.01$ signifies that the gaps differ significantly.

A multiple comparison procedure was carried out further to locate the differences with some results presented in Table 4, Panel C. The absolute difference in rank totals for Pair 3 is less than 95.93. Hence, it indicated that there is no significant difference in gaps between Beneish and Altman models, i.e., the capability of Beneish M-score model and Altman Z-score model is similar. Therefore, the gap differs significantly only for Dechow's model. Additionally, we ran the Mann-Whitney test to examine whether there is significant difference in FDG between international and local audit firms across the models. The results are presented in Table 5.

The result showed that the $\mathrm{Z}$ statistics for Beneish M-score model is -2.33 and significant at the p-value of .020. Hence, there is evidence that Beneish M-score model can detect fraud financial statements between international and local firms. This evidence suggested of significant FDG differences between international (mean gap between auditor and model for international firms $=-0.02$ ) and local audit firms (mean gap between auditor and model for local firms $=-0.13$ ). Meanwhile, the Dechow F-score and Altman $\mathrm{Z}$-score models are insignificant. Hence, there is an

TABLE 4. Univariate Analysis Results

Panel A: Wilcoxon Test

\begin{tabular}{lccc}
\hline \multicolumn{4}{c}{ Auditor's Fraud Detection Gap } \\
\hline & & Fraud Detection Model & \\
& Dechow F-Score & Beneish M-Score & Altman Z-Score \\
\hline Z & $-8.130^{\mathrm{b}}$ & $-1.264^{\mathrm{b}}$ & $-.070^{\mathrm{b}}$ \\
Asymp. Sig. (2-tailed) & .000 & .206 & .944 \\
\hline
\end{tabular}

a. Wilcoxon Signed Ranks Test

b. Based on negative ranks.

Panel B: Friedman Test

\begin{tabular}{ll}
\hline $\mathrm{N}$ & 1095 \\
\hline Chi-Square & 38.087 \\
$\mathrm{Df}$ & 2
\end{tabular}

Asymp. Sig. $\quad .000$

Model Fa. Friedman Test

Panel C: Multiple Comparison Test

\begin{tabular}{lcc}
\hline Pair & Absolute difference in rank totals & Benchmark \\
\hline Dechow vs Beneish (Pair 1) & 120.45 & 95.93 \\
Dechow vs Altman (Pair 2) & 109.50 & 95.93 \\
Beneish vs Altman (Pair 3) & 10.95 & 95.93 \\
\hline
\end{tabular}

TABLE 5. Mann-Whitney Test

\begin{tabular}{lccc}
\hline \multicolumn{3}{c}{ Auditor's Fraud Detection Gap } \\
\hline & & Fraud Detection Model & \\
& Dechow F-Score & Beneish M-Score & Altman Z-Score \\
\cline { 2 - 3 } Mann-Whitney U & 38650.00 & 36054.50 & 38310.50 \\
Wilcoxon W & 555286.00 & 39214.50 & 554946.50 \\
Z & -0.87 & -2.33 & -1.02 \\
Asymp. Sig. (2-tailed) & 0.39 & 0.02 & 0.31 \\
\hline
\end{tabular}

a. Grouping Variable: Status of company 
evidence for FDG's differentiation of ability to detect fraud financial statements between international and local audit firms (Asymp. Sig. (2-tailed) is 0.02, less than 0.05) based on the Beneish M-score model. However, there is insignificant difference between international and local audit firms for the Dechow F-score and Altman Z-score models.

As mentioned earlier, care has to be taken in interpreting this finding due to the imbalanced sample observations. For the results to be more meaningful and reliable, the breakdown of the number of observations for both groups should be in the ratio of $60 \%: 40 \%$ or $70 \%$ : $30 \%$ (Hair et al. 2010). Since the breakdown is $92 \%: 8 \%$, it is safe to conclude that comparisons between international and local audit firms in this study are not entirely robust in explaining the fraud detection gap. We perform additional analysis to confirm whether status of audit firm either international or local is related to FDGs (using Dechow F-Score model). This hypothesis is tested based on the Chi-square test of independence. A summary of the test of independence is provided in Table 6 .

TABLE 6. Relationship Analysis

\begin{tabular}{lccc}
\hline & $\begin{array}{c}\text { Dechow } \\
\text { F-Score }\end{array}$ & $\begin{array}{c}\text { Beneish } \\
\text { M-Score }\end{array}$ & $\begin{array}{c}\text { Altman } \\
\text { Z-Score }\end{array}$ \\
\hline Pearson Chi-Square & 0.781 & 6.931 & 4.638 \\
p-value & 0.677 & 0.031 & 0.098 \\
Cramers V statistic & 0.027 & 0.080 & 0.065 \\
p-value & 0.677 & 0.031 & 0.098 \\
\hline
\end{tabular}

The result for the Pearson Chi-Square shows that the value for Beneish M-score model is 6.931 and significant at a level p-value of $0.031,<0.01$. It can be concluded that status of audit firm (international/local) is significantly related to FDG based on Beneish M-Score model. Insignificant relationships were found for the other two models. This finding supported the significant FDG differences which was found between international and local companies using the Beneish F-Score model. This is suggested that Beneish M-Score model is more effective in detecting for companies associated with local audit firms as compared to international audit firms.

\section{MULTIVARIATE ANALYSIS}

We also ran a binary logistic regression to examine whether the FDG is associated with audit quality either Big 4 or non-Big 4 auditors. We regressed the relationship by using the following equation:

$\mathrm{FDG}=\beta_{0}+\beta_{1} \mathrm{Big} 4+\beta_{2}$ BInd $+\beta_{3}$ ACInd $+\beta_{4}$ FSize + $\beta_{5}$ FLev $+\beta_{6}$ ProfitM $+\beta_{7}$ ROA $+\beta_{8} \sum^{6}$ Industry $+\beta_{9} \sum^{3}$ Years $+\beta_{10} \sum^{5}$ Countries $+\varepsilon$

Where, $F D G$ is an auditor's fraud detection gap, measured as a dummy variable, equal to 1 if the $F D G$ existed, otherwise $0 ;$ Big4 represented quality of the audit services, measure as a dummy, equal to 1 if the companies appoint Big 4 auditor, and 0 otherwise; BInd is a board independence, measured by ratio of independent directors over total board members; ACInd is an audit committee independence, measured by ratio of independent directors over total audit committee members; FSize is a firm size, measured as a natural logarithm of the companies' total assets; FLev is a firm leverage, measured by scaling the companies' total debts over total assets; Profit $M$ is a gross profit margin, which measured by dividing gross profit to total sales; $R O A$ is return on assets, calculated by scaling the companies' net earnings to total assets; $\varepsilon$ is representing an error term.

We included control variables to include the crosssectional effect of companies and corporate governance practice differences, which may affect the results for the association between Big 4 auditors and FDGs. The control variables include board independence (BInd), audit committee independence (ACInd), firm size (FSize), firm leverage (FLev), gross profit margin (ProfitM), and return of asset (ROA) influence fraud detection gap. The logistic model obtained is evaluated to indicate how well the model performs in predicting fraud detection gap by using several procedures such as classification table, Omnibus tests, Hosmer - Lemeshow goodness of fit test, Cox \& Snell R -Square and Nagelkerke R square tests.

The regression results for each of the three models are tabulated in Table 7. The Cox \& Snell R square value and the Nagelkerke R square value for the Altman model produce the largest value suggesting that greater variability in fraud detection gap is explained by the ten variables based on this model as compared to Dechow and Beneish models. It is a known fact that in logistic regression, both of these measures (Cox \& Snell R square value and the Nagelkerke R square value) are not good indicators of the usefulness of the model as R-square value provided in multiple regression output. Other more reliable test such as the Omnibus test is performed to support the significance of the model. The results for the Omnibus test for all models are also provided in Table 7 . The large Chi-square values of 56.47, 42.66 and 113.81, respectively, and small $p$-values of less than 0.05 imply all models are highly significant. In contrast, the Hosmer - Lemeshow goodness of fit test shows small Chi-square values of between 3.52 and 9.76 and $p$-values of more than 0.05 which indicates good fit. These findings support all the three models. The contribution of each of the ten predictor variables towards the FDG (dependent variable) can be observed through the Wald test.

Across the board, it is seen that the Altman model has a positive relationship with the FDG. The coefficient for Big4 is $\beta=0.445$ (Wald $=4.99$ ), significant at $p<0.05$. This result indicated that the FDG increase when the Big4 audit firms predict the financial statement's fraud by using the Altman Z model. In contrast, the Beneish model showed a negative relationship between Big4 and FDG. The coefficient for Big4 is $\beta=-0.352$ (Wald=3.46), significant 
TABLE 7. Multivariate Analysis

\begin{tabular}{lccc}
\hline & Model FDG-Dechow & Model FDG-Beneish & Model FDG-Altman \\
\cline { 2 - 4 } & $\beta$ (Wald) & $\beta$ (Wald) & $\beta$ (Wald) \\
\hline Constant & $-0.667(0.59)$ & $-1.918(5.01)^{* *}$ & $-0.709(0.68)$ \\
Big4 & $-0.260(1.79)$ & $-0.352(3.46)^{*}$ & $0.445(4.99)^{* *}$ \\
BInd & $0.131(0.82)$ & $-0.009(0.01)$ & $0.543(16.18)^{* * *}$ \\
ACInd & $-0.250(0.48)$ & $-0.310(0.88)$ & $-0.043(0.01)$ \\
FSize & $-0.027(0.24)$ & $0.003(0.00)$ & $-0.088(2.70)^{*}$ \\
FLev & $-0.007(1.85)$ & $0.000(0.00)$ & $-0.022(14.09)^{* * *}$ \\
ProfitM & $-0.001(0.32)$ & $0.000(0.22)$ & $-0.002(2.71)^{*}$ \\
ROA & $-0.001(0.01)$ & $-0.001(0.01)$ & $0.059(29.35)^{* * *}$ \\
Industry & Included & Included & Included \\
Year & Included & Included & Included \\
Country & Included & Included & Included \\
N (observations) & 1,095 & 1,095 & 1,095 \\
Cox \& Snell R & 0.05 & 0.04 & 0.10 \\
Nagelkerke R & 0.09 & 0.07 & 0.16 \\
Omnibus (Chi-square) & $56.47^{2 * *}$ & $42.66 * * *$ & $113.81^{* * *}$ \\
Hosmer and Lemeshow (Chi-square) & 4.99 & 3.52 & 9.76 \\
\hline
\end{tabular}

Notes: ***,*** significant at a level $10 \%, 5 \%$ and $1 \%$ respectively. Please refers to Equation 1 for definition and measurements of the variables. Industry, Years and Countries are not tabulated for brevity.

at $\mathrm{p}<0.10$. The results suggested that the FDG is reduced when the Big4 utilize the Beneish M model to detect the financial statement's fraud. However, it was found that the relationship between FDG F- model and auditors from Big4 is insignificant.

In overall, the results of these three models look inconsistent. We concern that predictors such as country and industry seem to have an impact on FDG for all three models even though at slightly different rate. To understand the Altman model better, some statistics from Table 7 is extracted and interpreted. The results are not tabulated for brevity. For this model, all comparisons will be made with respect to non-big 4, Saudi Arabia, service sector and year 2015, which is also referred to as the referent groups. For example, the statistics related to Bahrain (Wald statistic $=$ $6.20, p$-value $<0.05$ ), the negative $\beta$ value of -1.446 and $\operatorname{Exp}(\mathrm{B})=0.236$ indicates that the odds of a company in Bahrain experiencing the gap is 0.236 times lower than a company in Saudi Arabia. In other words, a company in Bahrain is less likely to experience the gap compared to a company in Saudi Arabia by $19.1 \%$. A Big 4 company in the Gulf States is more likely to encounter FDG compared to a non-big 4 by $60.9 \%$ (Wald statistic $=4.99$, $p$-value $<$ $0.05, \beta$ value $=0.445$ and $\operatorname{Exp}(B)=1.560$.

Hence, to conclude although the models are found to be significant, the percent increment of identifying fraud companies based on the ten predictor variables is very minimal. The prediction of fraud companies works equally well even without it (as shown from the results obtained from the multivariate analysis table and classification table discussed below) as the classification table indicated that it can correctly classified more than $80 \%$ of the cases.

\section{CONCLUSION}

This study investigated the FDG in the GCC companies by comparing the results of the Beneish M-score, Dechow F-score, and Altman Z-score as the fraud detection models. The results showed that the rate of fraud detection obtained by Dechow F-score is much higher than the rate obtained by auditors, Beneish M-score and Altman Z-score. Moreover, the findings are supported by gap analysis based on the detection gap between the auditors and each of the other three models and indicate that the rate of fraud detection obtained by the auditors differ from the rate obtained by the Dechow F-score which proved that the Dechow F-score is able to detect higher cases of fraud. On the other side, the rate obtained by Beneish M-score confirmed that this model can detect fraud of companies with local audit firms better than companies with international audit firms. Therefore, this study supports the superiority of Dechow F-score in fraud detection compared with auditors, Beneish M-score and Altman Z-score.

The limitation of the study is, it only has nonfinancial companies listed on GCC for three years (20152017). Hence, there was no generalized finding. The recommendation is to consider financial companies and variables affecting the FDG such as; corporate governance, 
involvement of royal family, auditor industry expertise and auditor reappointment tenure for future studies to obtain generalized finding.

\section{NOTES}

1. Some of the fraud detection models that have gained professional and academic attention include Beneish model, Jones model, Altman Z-Score and the Dechow F score.

\section{REFERENCES}

Aghghaleh, S. F., Mohamed, Z. M., \& Rahmat, M. M. 2016. Detecting Financial Statement Frauds in Malaysia: Comparing the Abilities of Beneish and Dechow Models. Asian Journal of Accounting and Governance 7: 57-65.

Albashrawi, M. 2016. Detecting financial fraud using data mining techniques: a decade review from 2004 to 2015. Journal of Data Science 14(3): 553-569.

Association of Certified Fraud Examiners. 2007. Detecting occupational fraud in Canada. A study of its victims and perpetrators.

Association of Certified Fraud Examiners. 2014. Report to the nations on occupational fraud and abuse 2014 global fraud study.

Association of Certified Fraud Examiners. 2016. Report to the nations on occupational fraud and abuse.

Al-Ghamdi, S., \& Ali, L. 2012. Investigation into earnings management practices and the role of corporate governance and external audit in emerging markets: Empirical evidence from Saudi listed companies (Doctoral dissertation, Durham University).

Altman, E. I. 2000. Predicting financial distress of companies: Revisiting the Z-score and ZETA models. Stern School of Business, New York University, 9-12.

Aris, N. A., Arif, S. M. M., Othman, R., \& Zain, M. M. 2015. Fraudulent financial statement detection using statistical techniques: The case of small medium automotive enterprise. Journal of Applied Business Research 31(4): 1469.

Baatwah, S. R. 2016. Audit Tenure and Financial Reporting in Oman: Does Rotation Affect The Quality?.

Bahrawe, S. H., Haron, H., \& Hasan, A. N. B. 2016. Corporate Governance and Auditor Independence in Saudi Arabia: Literature Review and Proposed Conceptual Framework. International Business Research 9(11): 1-15.

Chan, D. Y., \& Vasarhelyi, M. A. 2018. Innovation and practice of continuous auditing. In Continuous Auditing: Theory and Application (pp. 271-283)

Che, L., Hope, O. K., \& Langli, J. C. 2018. How big-4 firms improve audit quality. Available at SSRN 2828224

Dechow, P. M., Ge, W., Larson, C. R., \& Sloan, R. G. 2011. Predicting material accounting misstatements. Contemporary Accounting Research 28(1): 17-82.

Fanning, K. M., \& Cogger, K. O. 1998. Neural network detection of management fraud using published financial data. International Journal of Intelligent Systems in Accounting, Finance \& Management 7(1): 21-41.

Gao, L., \& Brink, A. G. 2017. Whistleblowing studies in accounting research: A review of experimental studies on the determinants of whistleblowing. Journal of Accounting Literature 38: 1-13.

Habib, A., \& Muhammadi, A. H. 2018. Political connections and audit report lag: Indonesian evidence. International Journal of Accounting \& Information Management 26(1): 59-80.

Hajek, P., \& Henriques, R. 2017. Mining corporate annual reports for intelligent detection of financial statement fraud-a comparative study of machine learning methods. Knowledge-Based Systems 128: 139-152.

Hair, J., Black, W. C., Babin, B. J., \& Anderson, R. E. 2010. Multivariate Data Analysis .7th ed. Upper Saddle River, New Jersey: Pearson Education International.

Hung, D. N., Ha, H. T. V., \& Binh, D. T. 2017. Application of F-Score in Predicting Fraud, Errors: Experimental Research in Vietnam. International Journal of Accounting and Financial Reporting 7(2): 303-322.

Hussey, R. 2010. Fundamentals of International Financial Accounting and Reporting. World Scientific Publishing Company.

Ittelson, T. R. 2009. Financial Statements: A Step-By-Step Guide to Understanding and Creating Financial Reports. Red Wheel/Weiser

Jian, M. \& Wong, T. J. 2010. Propping through related party transactions. Review of Accounting Studies 15(1): 70-105.

Krambia-Kapardis, M. 2010. Neural networks: The panacea in fraud detection? Managerial Auditing Journal 25(7): 659678

Kozlov M., Hurtado-Guarin J. \& Trakulhoon P. 2018. Forensic Accounting: Detecting Financial Fraud.

Kwok, B. K. 2017. Accounting irregularities in financial statements: A definitive guide for litigators, auditors and fraud investigators. Routledge.

MacCarthy, J. 2017. Using Altman Z-score and Beneish M-score Models to Detect Financial Fraud and Corporate Failure: A Case Study of Enron Corporation. International Journal of Finance and Accounting 6(6): 159-166.

Mahama, M. 2015. Detecting corporate fraud and financial distress using the Altman and Beneish models. International Journal of Economics, Commerce and Management 3(1): $1-18$.

Mahama, M. 2015. Assessing the state of financial distress in listed companies in Ghana: Signs, sources, detection and elimination-A Test of Altman's Z-Score. European Journal of Business and Management 7(3): 1-10.

Mangala, D., \& Kumari, P. 2017. Auditors' Perceptions of the Effectiveness of Fraud Prevention and Detection Methods. Indian Journal of Corporate Governance 10(2): 118-142.

Ofori, E. 2016. Detecting corporate financial fraud using Modified Altman Z-score and Beneish M-score. The case of Enron Corp. Research Journal of Finance and Accounting 7(4): 59-65.

Omar, N., Koya, R. K., Sanusi, Z. M., \& Shafie, N. A. 2014. Financial statement fraud: A case examination using Beneish Model and ratio analysis. International Journal of Trade, Economics and Finance 5(2): 184.

Paik, D. G., Kim, T., Krumwiede, K., \& Lee, B. B. 2018. The Association between Audit Fees and Accounting Restatement Resulting from Accounting Fraud and Clerical Errors. Journal of Forensic \& Investigative Accounting 10(3).

Pietro Pavone. 2018. Accounting Frauds and Evaluative Discretion Areas: Anomalies in the Adoption of the Ias 36. Eurasian Journal of Social Sciences 6(2): 37-45. 
PwC .2016. Global Economic Crime Survey Middle East Report.

Rahmat, M. M., Amin, H. a. M. \& Saleh, N. M. 2018. Controlling Shareholders' Proxy and Multiple Directorships: Insight Evidence from Related Party Transactions. Asian Journal of Accounting and Governance 9(1): 27-40.

Ramady, M. A. (Ed.). 2012. The GCC Economies: Stepping up to Future Challenges. Springer Science \& Business Media.

Ravisankar, P., Ravi, V., Rao, G. R., \& Bose, I. 2011. Detection of financial statement fraud and feature selection using data mining techniques. Decision Support Systems 50(2): 491-500.

Repousis, S. 2016. Using Beneish model to detect corporate financial statement fraud in Greece. Journal of Financial Crime 23(4): 1063-1073.

Rezaee, Z. \& Riley, R. 2010. Financial Statement FraudPrevention and Detection, Hoboken, John\&Wiley Sons. Inc., New Jersey.

Silverstone, H. \& Sheetz, Michael. 2004. Forensic Accounting and Fraud Investigation for Non-Experts. New Jersey: John Wiley \& Sons.

Stephens, N. 2011. External auditor characteristics and internal control reporting under SOX section 302. Managerial Auditing Journal 26(2): 114-129.

Wells, J. 2002. Let Them Know Someone's Watching. Journal of Accountancy 193(5): 106-110.

Wells, J. T. 2017. Corporate Fraud Handbook: Prevention and Detection. John Wiley \& Sons.

Zack, G. M. 2012. Financial Statement Fraud: Strategies for Detection and Investigation. John Wiley \& Sons.
Tahani Ali Hakami*

Fakulti Ekonomi dan Pengurusan

Universiti Kebangsaan Malaysia

43600 UKM Bangi Selangor

MALAYSIA

Faculty of Business Administration,

Jazan University,

Jazan, Saudi Arabia

E-mail: thakami@jazanu.edu.sa

Mohd Mohid Rahmat

Fakulti Ekonomi dan Pengurusan

Universiti Kebangsaan Malaysia

43600 UKM Bangi Selangor

MALAYSIA

E-mail: mohead@ukm.edu.my

Mohd Hasimi Yaacob

Fakulti Ekonomi dan Pengurusan

Universiti Kebangsaan Malaysia

43600 UKM Bangi Selangor

MALAYSIA

E-mail: mhasimi@ukm.edu.my

Norman Mohd Saleh

Fakulti Ekonomi dan Pengurusan

Universiti Kebangsaan Malaysia

43600 UKM Bangi Selangor

MALAYSIA

E-mail: norman@ukm.edu.my

*Corresponding author 